\title{
A VONTADE DO IMPOSSÍVEL, DE GEORGES BATAILLE ${ }^{1}$
}

\section{Tradução de Fernando Scheibe}

A noite estrelada é a mesa de jogo sobre a qual o ser se joga: lançado através desse campo de efêmeros possíveis, caio lá de cima, desamparado, como um inseto de costas.

Nenhuma razão para julgar a situação ruim: ela me apraz, me enerva e me excita.

Se eu fosse da "natureza estática e dada", estaria limitado por leis fixas, devendo gemer em certos casos, gozar em outros. Jogando-me, a natureza me relança para além dela mesma... - para além dos limites e das leis que fazem com que a louvem os humildes. Pelo fato de ser jogado, sou um possível que não era. Excedo todo o dado do universo e coloco a natureza em jogo.

Sou, no seio da imensidão, o plus, a exuberância. O universo podia passar sem mim. Minha força, minha impudência decorrem desse caráter supérfluo.

Submetendo-me ao que me cerca, interpretando, transformando a noite numa fábula para crianças, renunciaria a esse caráter. Inserido na ordem das coisas, teria que justificar minha vida - nos planos misturados da comédia, da tragédia, da utilidade.

Mas, recusando, me revoltando, não devo perder a cabeça.

É natural demais delirar.

O delírio poético não consegue desafiar a natureza inteiramente: ele a justifica, aceita embelezá-la. A recusa pertence à consciência clara, que mede sua posição com uma atenção calma.

A distinção dos diversos possíveis e, por conseguinte, a faculdade de ir ao extremo do mais longínquo, pertence à atenção calma.

Cada um pode, se assim quiser, dar sua benção a uma natureza amparadora, curvar-se diante de Deus...

Nada há em nós que não seja constantemente jogado, portanto abandonado.

A aspereza súbita da sorte desmente a humildade, desmente a confiança. A verdade responde como uma bofetada à bochecha estendida dos humildes.

O coração é humano na medida em que se revolta. Não ser besta, mas um homem, significa recusar a lei (aquela da natureza).

\footnotetext{
${ }^{1}$ La volonté de l'impossible. Revista Vrille, 1945, número dedicado a "A pintura e a literatura livres". Sob o título Etre Oreste [Ser Oreste], outra versão deste artigo foi publicada, em 1947, como parte final do livro - "de ficção" - Haine de la poésie [Ódio pela poesia], reeditado em 1962 como L'impossible.
} 
Um poeta não chega a justificar a natureza. A poesia é fora da lei. No entanto, aceitar a poesia a transforma em seu contrário, em mediadora de uma aceitação. Afrouxo a mola que me tensiona contra a natureza, justifico o mundo dado.

A poesia faz a penumbra, introduz o equívoco, afasta ao mesmo tempo da noite e do dia - da colocação em questão e da colocação em ação do mundo.

Não é evidente? A ameaça constantemente mantida de que a natureza nos triture, nos reduza ao dado - anule assim o jogo que ela joga mais longe que ela mesma -, solicita em nós a atenção e a astúcia.

O relaxamento retira do jogo - e da mesma forma o excesso de atenção. $O$ arrebatamento feliz, os saltos razoáveis e a calma lucidez são exigidos do jogador - até o instante em que a sorte lhe faltará, ou a vida.

Aproximo-me da poesia com uma intenção de trair: o espírito de astúcia é o mais forte em mim.

A força derrubadora da poesia se situa fora dos belos momentos que ela atinge: comparada a seu fracasso, a poesia rasteja.

$\mathrm{O}$ comum acordo situa à parte os dois autores que juntaram o brilho de seu fracasso àquele de sua poesia.

O equívoco está geralmente ligado a seus nomes. Mas um e outro esgotaram o movimento da poesia - que se completa em seu contrário: num sentimento de impotência da poesia.

A poesia que não se eleva até a impotência da poesia é ainda o vazio da poesia (a bela poesia).

A via em que o homem se meteu, ao colocar a natureza em questão, é essencialmente negativa. Vai de contestação em contestação. Só se pode segui-la em movimentos rápidos e logo quebrados. A excitação e a depressão se sucedem.

O movimento da poesia parte do conhecido e conduz ao desconhecido, toca a loucura, se chega a se completar. Mas o refluxo começa quando a loucura está próxima.

O que se dá por poesia não é dela, em geral, mais que o refluxo: humildemente, o movimento em direção à poesia quer permanecer nos limites do possível. A poesia é,o que quer que se faça, uma negação de si mesma.

A negação, em que a poesia ultrapassa a si mesma, tem mais consequência que um refluxo. Mas a loucura não tem mais que a poesia o meio de se manter em si mesma. Há poetas e loucos (e macacos de uns e de outros): poetas e loucos não são mais que momentos de parada. O limite do poeta é da mesma natureza que o do louco na medida em que só é atingido pessoalmente, não sendo limite da vida humana. O tempo de parada marcado deixa apenas a destroços um meio de se manterem em si mesmos. $\mathrm{O}$ movimento das águas não é por isso retardado. 
A poesia não é conhecimento de si mesmo, ainda menos a experiência do mais longínquo possível (daquilo que, antes, não era), mas a evocação pelas palavras dessa experiência.

A evocação tem sobre a experiência propriamente dita a vantagem de uma riqueza e de uma facilidade infinitas, mas afasta da experiência (em primeiro lugar pobre e difícil).

Sem a riqueza entrevista na evocação, a experiência seria sem audácia e sem exigência. Mas ela começa somente se o vazio - o embuste - da evocação desespera.

A poesia abre o vazio ao excesso do desejo. $\mathrm{O}$ vazio deixado pela devastação da poesia é em nós a medida de uma recusa - de uma vontade de exceder o dado natural. A poesia ela própria excede o dado, mas não pode mudá-lo. Ela substitui a servidão dos laços naturais pela liberdade da associação verbal - a associação verbal destrói os laços que quisermos, mas verbalmente.

A liberdade ficcional assegura mais que arruína a coação do dado natural. Quem com ela se contenta, no longo prazo, está de acordo com esse dado.

Se persevero na colocação em questão do dado, percebendo a miséria de quem com ele se contenta, não posso suportar por muito tempo a ficção: dela exijo a realidade, fico louco.

Minha loucura pode tocar o mundo de fora, exigindo que o mudem em função da poesia. Se a exigência é virada para a vida interior, exige uma potência que só pertence à evocação. Num caso como no outro, faço a experiência do vazio.

Se minto, permaneço no plano da poesia, da superação fictícia do dado. Se persevero num descrédito obtuso desse dado, meu descrédito é falso (da mesma natureza que a superação): a crítica do mundo real a partir da poesia é o sobrelanço das mentiras. Em certo sentido, o acordo com o dado se aprofunda. Mas não podendo mentir cientemente, fico louco (não percebendo mais a evidência). Ou, não sabendo mais, para mim só, representar a comédia de um delírio, fico louco também, mas interiormente: faço a experiência da noite.

A poesia não é mais que um desvio: escapo por ela ao mundo do discurso, ou seja, ao mundo natural (dos objetos): entro por ela numa sorte de túmulo onde, da morte do mundo lógico, nasce a infinidade dos possíveis.

O mundo lógico morre parindo as riquezas da poesia, mas os possíveis evocados são irreais, a morte do mundo real é irreal; tudo é suspeito e fugidio nesta obscuridade relativa: nela posso zombar de mim-mesmo e dos outros. Todo o real é sem valor, e todo valor é irreal. Daí essa fatalidade e essa facilidade de deslizamentos em que ignoro se minto ou se estou louco. Dessa situação pegajosa procede a necessidade da noite.

A noite não podia evitar esse desvio. A colocação em questão nasceu do desejo, que não podia incidir sobre o vazio. 

desilusão.

O objeto do desejo é em primeiro lugar o ilusório, apenas em segundo o vazio da

A colocação em questão sem desejo é formal, indiferente. Não é dela que se pode dizer: é a mesma coisa que o homem.

A poesia se deve ao poder do desconhecido (o desconhecido, valor essencial). Mas o desconhecido não é mais que um vazio branco se não for objeto do desejo. $\mathrm{O}$ poético é o meio termo: é o desconhecido mascarado com cores brilhantes e com a aparência do ser.

Ofuscado por mil figuras em que se combinam o tédio, a impaciência e o amor, meu desejo não tem mais que um objeto: o além dessas mil figuras é o vazio que destrói o desejo.

Tendo permanecido ofuscado, sabendo - tendo a vaga consciência de - que as figuras dependem da facilidade (da ausência de rigor) que as fez nascer, posso voluntariamente manter o equívoco. A desordem então e a pouca satisfação me dão a impressão de estar louco.

As figuras poéticas, devendo seu brilho a uma destruição do real, permanecem à mercê do nada, devem roçá-lo, tirar dele o aspecto suspeito e desejável delas: têm já do desconhecido a estranheza, os olhos de cego.

O rigor é hostil a quem as ama, ele significa a pobreza prosaica.

Se eu tivesse mantido o rigor em mim? Não teria conhecido as figuras do desejo. Meu desejo despertou aos clarões da desordem, no seio de um mundo transfigurado. Mas, uma vez o desejo desperto? Se volto ao rigor?

$\mathrm{O}$ rigor dissipando as figuras poéticas, o desejo está enfim dentro da noite.

A existência, dentro da noite, é como um amante diante da morte da amante (Orestes à notícia do suicídio de Hermione). Ela não pode, na espécie da noite, reconhecer aquilo que esperava.

O desejo não pode de antemão saber que tinha por objeto sua própria negação. A noite em que soçobram como vazios não somente as figuras do desejo mas todo e qualquer objeto de saber é penosa. Todo valor nela é anulado. 